Università degli Studi di Salerno

Centro di Economia del Lavoro e di Politica Economica

Gianluigi Coppola

UNIVERSITA' DEGLI STUDI DI SALERNO - C.E.L.P.E.

Health, Lifestyle and Growth

Corresponding author:

glcoppola@unisa.it

Discussion Paper 115 


\section{Scientific Commitee:}

Adalgiso Amendola, Floro Ernesto Caroleo, Cesare Imbriani, Pasquale Persico

\section{C.E.L.P.E.}

Centro di Ricerca Interdipartimentale di Economia del Lavoro e di Politica Economica Università degli Studi di Salerno

Via Ponte Don Melillo, 84084 Fisciano, I- Italy

http://www.celpe.unisa.it

E-mail: celpe@unisa.it 


\section{Index}

Abstract

Introduction

1. Some Empirical Evidence

2. A Micro Model

3. Comparative Static: The Health Multiplier

4.A Growth Model with Health

5. Conclusions

18

Appendix

21

References

23

CELPE's Discussion Paper 


\title{
Health, Lifestyle and Growth
}

\author{
Gianluigi Coppola \\ Dipartimento di Scienze Economiche e Statistiche- \\ C.E.L.P.E.
}

To Angelo and Angelica

\begin{abstract}
In this paper I will try to explain why lifestyle may have a positive impact on economic growth. First of all, I consider health affecting consumer's utility and then define a Health Production Function where health is the output and consumer good the input. In this approach a parameter named Lifestyle Return to Scale (LRS) is defined. The first result is that an increase of consumer's personal income may have a positive or a negative effect on health. In other words health may be a normal or an inferior good. It depends on Lifestyle Return to Scale- According to this result, I compute a health multiplier and then modify the Solow Growth Model in which health is labour-augmenting. The result is a model in which the Lifestyle Return to Scale positively affects the income per capita and the income per capita growth.
\end{abstract}

JEL Classification: I10, O40

Keywords: Health, lifestyles, growth 


\section{Introduction}

At the macro level the stylized facts show a big difference in income per capita and in Health status among countries and/or regions. This may imply that low income per capita negatively affects health and vice versa.

It is useful to note that in the last 20 years literature on economic growth focused primarily on the role of human capital accumulation while health had a marginal role in the economic analysis. Secondly, if the differences among countries are strong (in income and in health), those among regions are even stronger and also very important for economic growth.

The literature on Health Economic Growth and Health has not considered the impact lifestyle has on Economic Growth.

The aim of this theoretical paper is to build the relationship between Health and Growth taking consumers' lifestyle into account.

Both the Wagstaff Model (1986) and Contoyannis and Jones's hypothesis (2004) introduced a micro model of consumer's choice in order to better define lifestyle and explain the effects of consumer's choices on its Health status. The first important result is that an increase of consumer's personal income may have a positive or a negative effect on its health if the same consumer has a "good" or a "bad" lifestyle.

At a macro level one of the most important questions for Weil (2005) is if the forces driving these differences among regions come primarily from health or from income? In this context I try to give an answer to this question computing a health multiplier (§ 2) and also developing a simple modified Solow growth model in which health is "labour augmenting" (§ 3$)$. For this reason this model includes the relationship among income, lifestyle and health status first obtained at micro level.

The main result of the model is that lifestyle may be crucial for growth: a "good" lifestyle can generate a positive impact on economic growth, but a "bad" consumer's lifestyle may also have negative effects on growth. The model also explains why health improvement has a positive effect on income while increasing in income may have a lower effect on health (Weil, 2005)

\section{Some Empirical Evidence}

The empirical evidence can be divided into two aspects. The first are the Long Run "stylized facts". The second aspect is related to some government measures that were taken in many states concerning the health of citizens.

The Long run "stylized facts" show an increase of income per capita and of life expectancy. From 1820 to 2001 the World GDP per capita has grown from \$ 667 to \$ 5,709 (Maddison, 2003). In the same period, the estimates of world life expectancy at birth has grown from 28,5 years (in the1820) to 65,2 years (in the1990).

The differences among the regions, both in terms of GDP per capita and life expectancy at birth have also grown (Riley, 2005). In 1998 the GDP per capita of the United States was 20 times the GDP per capita of Africa (in 1820 it was only three 
times).

In 1800-1820 the differences among regions in terms of life expectancy at birth were relatively low comparatively to the period 1990-2001. In the first period there were only 9,2 years from the highest to the lowest regional life expectancy. This gap widened to 26,3 years in the period1990-2001 (Riley, 2005).

These disparities may be explained by the differences in Public Health, Medical diagnostic and Medical care, and also diet and, more generally lifestyle.

As regards the second aspect, the government measures, a lot of evidence of the importance that people's lifestyle assumes exists.

For example, in England many local governments offer incentives in order to encourage the consumer to have a healthier lifestyle. In Dundee, smokers are being offered $£ 12.50$ a week by the NHS if carbon monoxide testing shows they have quit. In Essex, pregnant women can claim a $£ 20$ food voucher from the NHS after stopping smoking for one week, $£ 40$ after four weeks and another $£ 40$ at the end of a year if they have still quit. Brighton offers children $£ 15$ for quitting smoking for 28 days, while overweight patients in Kent are also being offered incentives for losing weight. In the US and other countries incentives have been offered for weight loss, complying with diabetes treatment, or regularly testing negative for sexually transmitted diseases" (Financial Times, Cash incentives seen as helping nation's health Financial Times 11 April 2009)

Moreover in Japan, a national law against the obesity came into effect in 2008 . Under this law companies and local governments must measure the waistlines of Japanese people between the ages of 40 and 74 during their annual checkups (New York Times, 2008).

In Italy phrases warning consumers of the damage that smoking causes are printed on cigarette packs (sold by a state monopoly) On some packages the following sentences even appear: smoking when pregnant harms your baby, smoking kills.

These few examples show how the government is concerned with the lifestyle of people and implement policies to change consumption habits of those persons. In other words, many governments are taking over the individual choices of people (as over-eating, smoking and drinking).

What determines the "intrusive" interest by the Government? By reasoning backward, the interest from the government assumes a conflict between individual choices and social choices. This conflict originates in two factors. The first is the rising cost of health care experienced in many Western nations.

The second is that a bad lifestyle may negatively affect labour productivity. At this purpose Zargosky (2005) shows for the U.S., a large negative association between Body Mass Index (BMI) and White female's net worth, a smaller negative association for Black women and White males and no relationship for Black male. He also finds that Individuals who lose small amounts of weight experience little change in net worth, but those who lose large amounts of weight have improved financial position.

Strauss (1986), for the Household of the Sierra Leone shows a highly significant effect of caloric intake on labour productivity, providing solid support for the nutrition- 
productivity hypothesis. The marginal effect on productivity falls drastically as calorie consumption rises but remains positive at moderately high levels of intake. One result is a fall in the effective price of food, a decline that is larger for households that consume fewer calories.

In general it can be argued that health has a positive effect on labour productivity of the individual. So the choices relating to lifestyle (smoking, drinking, etc) of the same individual interest the firm and indirectly the whole society because they produce effects on labour productivity of that person.

Ultimately lifestyle generates externalities, this term indicate possible conflicts not resolved by the market. Externalities have more weight on labour productivity and on the costs of health care than the company has to bear. This relatively new concept of externality is well explained by Sassi and Hurst (2008): “......... Lifestyle choices, as many other forms of consumption, may produce external effects. There are immediate externalities that derive directly from acts of lifestyle consumption, such as passive smoking, violent and disorderly behaviour associated with alcohol abuse, or traffic accidents resulting from reckless driving. There are also deferred externalities, which are generated through the link between lifestyle choices and chronic diseases. Once chronic diseases emerge, and in some cases even before they emerge (e.g. when important risk factors such as hypertension or obesity begin to manifest themselves), the individuals affected will become less productive, possibly entirely unproductive, they will make a more intensive use of medical and social services, which may be publicly funded, they may require care by members of the family and friends. Conversely, a reduced life expectancy may mean a less prolonged use of publicly funded medical and social services at the end of life, as well as reduced pension payments, which are not themselves externalities, but would translate into a less onerous fiscal burden and therefore less distortion in the way the economy works. All of these phenomena involve externalities (negative the former, positive the latter) on society at large, family and friends, which can be attributed at least to some extent to the lifestyle choices originally made by the individual. The extent to which externalities can be associated with lifestyle choices depends, of course, on the strength of the link between lifestyles and disease, i.e. by the increase in the risk of developing a chronic disease associated with adopting a particular lifestyle".

\section{A Micro Model}

In this paragraph I define lifestyle and develop a micro-funded model that explains the relationship between health and income, the effect of income on health.

First of all, let us suppose that an economy produces 3 goods: 2 consumption good ( $x$ and $\mathrm{z}$ ), and Capital (K). Saving rate (s) is exogenous and constant

According to the Grossman model (1972) health capital and demand for health have been widely modelled in economic literature.

Among others, Contoyannis and Jones (2004) develop a static model of lifestyle and health production. In this model: $i$ ) income is assumed to be endogenous, but there is no direct influence of lifestyle or health on wages; ii) health affects consumer's utility (unlike Grossman's dynamic model (1972) in which health is considered a stock that 
produces a flows of pecuniary and non pecuniary benefits as effect on investment on it). iii) health is a result of production function in which the inputs are i) a vector of goods, ii) a vector of exogenous influences on health; iii) a vector of unobservable influences on health. iv) The money budget constraint and the time constraint close the model. The result is that maximizing the Consumer's utility with a Lagrangian function, the Marshallian demand for the goods, and the level of consumer's Health is obtained.

In Contoyannis and Jones (2004) the Health Production Function is equal to

$$
H=h\left(C, X_{U}, U_{H}\right)
$$

Where $H$ is a measure of the individual health, $C$ is a vector of M-goods, $X_{U}$ is a vector of exogenous variables that influences health, and $U_{H}$ a vector of unobservable influence on health.

In this paper I simplify and modify Contoyannis and Jones (2004) building-up a model of 2 equations: 1) the consumer's utility function; 2 ) the health production function.

\section{The consumer's utility function}

I assume that the consumer's utility function is a Cobb Douglas where health $(h)$ is an input and for this reason it affects the consumer's utility function. The other 2 inputs are the goods $x$ and $z$. In Formula the utility function is:

$$
\begin{aligned}
& U(h, x, z)=h^{\alpha} x^{\beta} z^{\delta} \\
& \alpha, \beta \text { and } \delta \text { are respectively the elasticity of } h, x \text { and } z ;
\end{aligned}
$$

$\alpha \geq 0$ may be considered the weight given to his own health by the consumer. If $\alpha=0$, health is not important for the consumer. On the contrary if $\alpha>0$ then health is important.

$\beta, \delta \neq 0$. If $\beta<0$ (or $\delta<0$ ) $x$, (or $z$ ) is not good but "bad" for the consumer (i.e. a medicinal $)^{1}$.

The individual consumes a good only if its elasticity is positive. We suppose that $\beta>0$ e $\delta>0$. So we have $\frac{d U(\cdot)}{d x}>0 ; \frac{d U(\cdot)}{d z}>0$.

We also suppose that $\frac{d^{2} U(\cdot)}{d x}<0 ; \frac{d^{2} U(\cdot)}{d z}<0$

This is clearly a static equation. There is no rational addiction, but positive value of the elasticity means that the consumer knows the good's ophelimity.

\footnotetext{
1 In the textbook a "bad" is an externality, something independent form the consumer's decision. Here a "bad" is a good that has a negativity impact on the utility of the consumer, and it can be used by the consumer according his own decision (i.e. a medicinal)
} 


\section{The Health Production Function (HPF)}

According Contoyannis and Jones (2004) consumption may affect consumer's health, and for this reason the consumer is a co-producer of his health. For the authors the utility maximisation problem is given by the equations

$$
\begin{aligned}
& \underset{C, H}{\operatorname{Max}} U\left(C, H, C, X_{U}, \mu_{U}\right) \\
& H=h\left(C, X_{U}, u_{H}\right)
\end{aligned}
$$

Differently from Contoyannis and Jones (2004), I assume that the consumption of a good may not only be better, or neutral for the consumer's health status, but it may also worsen it. This may be, for example, smoking, alcohol and drugs.

For simplicity, let us assume that a good can only better or worsen consumer's health status. In other words, there are no goods that can have a positive impact on health for small quantities and a negative for stronger doses. It assumes also that $x$ improve health, while $z$ worst health ${ }^{2}$. The good $x$ can be defined as the virtuous good- in the sense of sustainable good - and $z$ as the harmful good.

Health also depends on the initial level of health status $\left(h_{0}\right)$, public health $(\Psi)$, time $t$ and on a stochastic component $\varepsilon$. The Health Production Function (HPF) is

$$
h\left(x, z, h_{0}, \psi, t, \varepsilon\right)=x^{\rho} z^{-\gamma} h_{0} \psi e^{\phi t} e^{\varepsilon}
$$

The equation can be split into two parts: $x^{\rho} z^{-\gamma}$ can be interpreted as the consumer's activity while the term $h_{0} \psi e^{\phi t} e^{\varepsilon}$ as other factors. To simplify things we put $\Omega=h_{0} \psi e^{\phi t} e^{\varepsilon}$ and HPF becomes:

$h(x, z, \Omega)=\Omega x^{\rho} z^{-\gamma}$

$(\rho-\gamma)$ is equal to the elasticity of scale and it can be positive, negative or null. Let $\theta=\rho-\gamma$. I suppose that each input exhibits decreasing return, as to say $0<\rho<1$ and $0<\gamma<1$, Therefore $-1<\theta<1$.

For Sassi and Hurst (2008) individual lifestyle is related to individual behaviour that occupies a central position among health, because of their direct influences on individual health. Also Contoyannis and Jones (2004) define a lifestyle "as a set of behaviours which are considered to influence health"

If $\theta>0$ an increasing of the consumption has a positive effect on health, while for $\theta<0$ this effect is negative. With $\theta=0$ the consumer behaviour has no effect on health. For this reason the parameter $\theta$ may be defined as the lifestyle Return to Scale (hereafter LRS).

Substituting $h(x, z, \Omega)=\Omega x^{\rho} z^{-\gamma}$ into $U(h, x, z)=h^{\alpha} x^{\beta} z^{\delta}$, it obtains

\footnotetext{
${ }^{2}$ The ancient Romans said “In Medius stat Virtus. That hypothesis doesn't matter in the model.
} 


$$
\begin{aligned}
& U(h, x, z)=\Omega x^{\alpha \rho} z^{-\alpha \gamma} x^{\beta} z^{\delta} \text { or } \\
& U(h, x, z)=\Omega x^{\alpha \rho+\beta} z^{\delta-\alpha \gamma}
\end{aligned}
$$

the $x$ 's elasticity become $a \rho+\beta$ and the elasticity of $z$ will be $\delta-a \gamma$. The good $z$ will be consumed only if $\delta-a \gamma>0$. Hence, the choice of consuming $z$ depends on 3 parameters: 1) the elasticity $\delta$ of the good $z$, as to say the weight that the consumer confers to that good $z$; 2) $\alpha$, the importance of the health for the consumer, 3 ) and the measure of the damage of $z$ on health $(\gamma)$.

It is useful to note that the consumer can decide to use $z$ even if he knows that $z$ is dangerous for his health ${ }^{3}$. Following this approach, it does not depend only on the level of education. Even the consumer well aware of the damage that smoking produces may continue to smoke if he likes it very much.

Including health in the consumer's utility function increases the consumption of those goods that benefit health and decreases that good which causes damage.

\section{The Utility maximization problem: The optimal choice of $x, z$ and $h$}

Let $\Omega=1 . p_{x} x+p_{z} z=c y$ is the consumer's budget constraint where $p_{x}, p_{z}$ are the prices of the goods. $y$ is the per capita income used for consumption $y=\frac{Y}{L}$ and $c$ is the average propensity to consume $(0<c<1)$ and $L$ is the population. The consumer maximizes his utility when $\operatorname{Max}_{x, z} x^{\alpha \rho+\beta} z^{\delta-\alpha \gamma}$ s.t $p_{x} x+p_{z} z=y^{4}$.

Solving the Lagrangianian $\max _{x, z} L=U(x, z)-\lambda\left(p_{x} x+p_{z} z-y\right)$. where $\lambda$ is the Langrage Multiplier. At the optimum the goods consumed are:

$$
\begin{aligned}
& x=\frac{\alpha \rho+\beta}{\beta+\delta+\alpha(\rho-\gamma)} \frac{c y}{p_{x}} \\
& z=\frac{\delta-\alpha \gamma}{\beta+\delta+\alpha(\rho-\gamma)} \frac{c y}{p_{z}}
\end{aligned}
$$

The weight of health, $\alpha$, increases the consumption of "virtuous" good and reduce the consumption of harmful good. At the optimum, the health level is

$$
h=\left(\frac{\alpha \rho+\beta}{\beta+\delta+\alpha(\rho-\gamma)} \frac{c y}{p_{x}}\right)^{\rho}\left(\frac{\delta-a \gamma}{\beta+\delta+\alpha(\rho-\gamma)} \frac{c y}{p_{z}}\right)^{-\gamma}
$$

\footnotetext{
${ }^{3}$ See (Avitabile, 2009) for the relationship between health and information

4 This approach may be considered also a generalization of Wagstaff's model (1986). See Appendix 1 for the details.
} 
or

$$
h=\left(\frac{\alpha \rho+\beta}{\beta+\delta+\alpha(\rho-\gamma)}\right)^{\rho}\left(\frac{\delta-\alpha \gamma}{\beta+\delta+\alpha(\rho-\gamma)}\right)^{-\gamma}\left(\frac{\left(p_{z}\right)^{\gamma}}{\left(p_{x}\right)^{\rho}}\right)(c y)^{(\rho-\gamma)}
$$

Where $\left(\frac{\alpha \rho+\beta}{\beta+\delta+\alpha(\rho-\gamma)}\right)^{\rho}$ and $\left(\frac{\delta-\alpha \gamma}{\beta+\delta+\alpha(\rho-\gamma)}\right)^{-\gamma}$ are respectively the share of good $\mathrm{x}$ and of good $\mathrm{z}$ weighted for their own elasticity with respect to health.

The level of health and the price of virtuous good are negatively correlated. If the price of good $x$ increases (decreases), it worsens (betters) the level of health while if it decreases then it improves health conditions. On the contrary $h$ improves (worsens) if the price of $z$ increases (decreases).

The elasticity of health with respect to income is $\rho-\gamma=\theta$, the parameter LRS. Unlike the other parameters that can have only one sign, the elasticity of health with respect to income may be positive or negative. If $\rho-\gamma=0$ income's growth do not affect the level of health. If $\rho-\gamma<0$, income affects health negatively. If $\rho-\gamma>0$ affects it positively.

In other words, an income growth does not always have a positive effect on health. The sign and the amount of the income's effect on health depends on the parameter $\theta$ of LRS.

A proxy (or an Index) of the consumer's Lifestyle (hereafter LI) may be given by the weighted average of the quantity of goods consumed for the respectively elasticity. The variable is included between by -1 and $1 .-1<L I<1$.

$$
L I=\rho\left(\frac{\alpha \rho+\beta}{\beta+\delta+\alpha(\rho-\gamma)}\right)-\gamma\left(\frac{\delta-\alpha \gamma}{\beta+\delta+\alpha(\rho-\gamma)}\right)
$$

Therefore, LRS $\theta$ is a crucial variable in the model because it indicates the attitude of the consumer, given his preference and his opportunity, to lead a particular lifestyle. In other words $\theta=\rho-\gamma$ partially and indirectly reflects the consumer's preferences because the health production function contains only those goods that consumer likes or that he can purchase ${ }^{5}$.

\footnotetext{
${ }^{5}$ Three issues are useful to underline. First, in this simple consumer's model, it is possible to choice between 2 goods. In the reality, a good may be not consumed for three reasons: 1) the consumer doesn't like that good, 2) even he likes that good he estimates the health's damage of that good greater than the good's utility, and he prefer to not consume that good; 3) he doesn't consume that good, because the relative price is greater than its income. In the first two cases do not consume the good is the result of free choice, (although painful in the second case). In the third case, the price of the asset and income limits the consumer's access to that good. In this paper we consider only the case in which the individues consume both goods.
} 


\section{Comparative Static: the Health Multiplier}

In the previous paragraph the effect of income on health has been found. We rewrite the Eq.11 as

$$
h=v\left(\frac{Y}{L}\right)^{\theta}
$$

Where $v=\left(\frac{\alpha \rho+\beta}{\beta+\delta+\alpha(\rho-\gamma)}\right)^{\rho}\left(\frac{\delta-\alpha \gamma}{\beta+\delta+\alpha(\rho-\gamma)}\right)^{-\gamma}\left(\frac{\left(p_{Z}\right)^{\gamma}}{\left(p_{x}\right)^{\rho}}\right) c$

Then I assume a production function with constant return to scale where both technology and health are labour augmenting. This may be a Cobb Douglas Production Function (i.e. Weil, 2005, Sala-I-Martin, 2005).

$$
Y=K^{a}(A h L)^{1-a}
$$

or

$$
\frac{Y}{L}=\left(\frac{K}{L}\right)^{a}(A h)^{1-a}
$$

From the system given by the equations [14] and [15] it is possible to quantify the impact of a "health shock" $(\Delta v)$ and/or an "income shock" $(\Delta A)$ on health and income.

\begin{tabular}{|c|c|c|}
\hline \multicolumn{3}{|l|}{ Scheme 1} \\
\hline & On Health & On Income \\
\hline & \multicolumn{2}{|c|}{$-1<\theta<1$} \\
\hline \multirow[b]{2}{*}{ Health shock } & $d \log h$ & $d \log Y$ \\
\hline & $\overline{d \log v}=\overline{1-\theta(1-\alpha)}$ & $\overline{d \log v}=\overline{1-\theta(1-\alpha)}$ \\
\hline \multirow{2}{*}{ Income shock } & $d \log h-\theta(1-\alpha)$ & $d \log Y$ \\
\hline & $\overline{d \log A}=\overline{1-\theta(1-\alpha)}$ & $\overline{d \log A}=\overline{1-\theta(1-\alpha)}$ \\
\hline
\end{tabular}

Solving this system we obtain the effects in terms of elasticity. The results are reported in the following scheme for $0<\theta<1$ compared with the case that $\theta=0$.

In terms of elasticity, the health multiplier is equal to $\frac{1}{1-\theta(1-\alpha)}$ for health and $\frac{1-\alpha}{1-\theta(1-\alpha)}$ for income.

For $0<\theta<1$, both of them are positive, and greater than one. As to say, if the lifestyle 
is positive, a health shock causes a greater effect on health, causing the effect of labour productivity growth.

The effect of a health shock on income depends positively on both LRS and labour elasticity or labour share.

The effect of an income shock on income is equal to $\frac{\theta(1-\alpha)}{1-\theta(1-\alpha)}$ and on health is equal to $\frac{(1-\alpha)}{1-\theta(1-\alpha)}$. Also in this case, for $0<\theta<1$, both of them are greater than zero.

Now It is also possible to give an answer to the question if a health shock causes a greater effect on income than an income shock on health (Weil, 2005): both a technological shock and a health shock produce the same effect on income. It is equal to $\frac{(1-\alpha)}{1-\theta(1-\alpha)}$ a that is greater than $(1-\alpha)$ because $\frac{1}{1-\theta(1-\alpha)}>1$.

Concerning health, a health shock has an impact equal to $\frac{1}{1-\theta(1-\alpha)}$, greater than an income shock $\frac{(1-\alpha)}{1-\theta(1-\alpha)}$ because $0<\theta<1$. Concerning income, a health shock has an impact on income $\frac{(1-\alpha)}{1-\theta(1-\alpha)}$ greater than an income shock on health $\frac{\theta(1-\alpha)}{1-\theta(1-\alpha)}$.

It is possible also to quantify the effect on health of a reduction of the price of the "good" $x$. The multipliers for income and for health are respectively equal to

$$
\begin{aligned}
& \frac{d \log h}{d \log p_{x}}=\frac{d \log h}{d \log v} \frac{d \log v}{d \log p_{x}}=-\frac{1}{1-\theta(1-\alpha)} \rho \\
& \frac{d \log Y}{d \log p_{x}}=\frac{d \log Y}{d \log v} \frac{d \log v}{d \log p_{x}}=-\frac{(1-\alpha)}{1-\theta(1-\alpha)} \rho
\end{aligned}
$$

The effect of $x^{\prime}$ s price shock on health is equal to $-\frac{1}{1-\theta(1-\alpha)} \rho$. It depends on the multiplier $\frac{1}{1-\theta(1-\alpha)}$ and on negatively on the parameter $\rho$ that is $\mathrm{x}^{\prime} \mathrm{s}$ elasticity on health. The impact on income is $-\frac{(1-\alpha)}{1-\theta(1-\alpha)} \rho$ the product of the impact of $\mathrm{x}^{\prime} \mathrm{s}$ price on health $-\frac{1}{1-\theta(1-\alpha)} \rho$ and health on income $(1-\alpha)$. Obviously it has a negative sign because a reduction of $x$ ' $s$ price, has a positive effect on health and also has a positive impact on income. 
The Scheme 2 reports the health multipliers in level

\begin{tabular}{|c|c|c|}
\hline \multicolumn{3}{|l|}{ Scheme 2} \\
\hline & On Health & On Income \\
\hline Health shock & $\frac{d h}{d v}=\frac{1}{1-\theta(1-\alpha)} Y^{\theta}$ & $\frac{d Y}{d v}=\frac{(1-\alpha)}{1-\theta(1-\alpha)} \frac{Y}{v}$ \\
\hline Income shock & $\frac{d h}{d A}=\frac{\theta(1-\alpha)}{1-\theta(1-\alpha)} \frac{h}{A}$ & $\frac{d Y}{d A}=\frac{(1-\alpha)}{1-\theta(1-\alpha)} \frac{Y}{A}$ \\
\hline
\end{tabular}

\section{A Growth Model with Health}

In the comparative static framework the level of population was constant. In this paragraph I develop a Growth Model including health as factor. In literature there are many models that consider health as a factor of growth. Lòpez-Casasnovas and others (2005). Rivera and Currais (1999a) use a conditional convergence regression where the growth of per capita income is a function of the determinants of the steady state and considering health as an important determinant of an enhanced labour force, they obtain the result that health affects income growth both positively and significantly. In an other paper (Rivera and Currais (1999b)) investment in health contributes in a significant way to explain variation in output through human capital even in those countries which have presumably high level of health.

Heshmati (2001) build up a model that is an extension of the MRW model by incorporating health. The results show that Health Care Expenditure has positive effect on the economic growth and on the speed of convergence

We would like to consider the effect of individual lifestyle on economic growth. Let us now consider a Solow Growth Model with constant saving rate (s), diminishing return of capital $(0<\alpha<1)$ and of labour, Labour augmenting technology, constant return to scale. We assume a Cobb Douglas production function:

$$
Y(t)=K(t)^{a}(A(t) L(t))^{1-a}
$$

where $K(t), A(t), L(t)$ are respectively the capital, the level of technology, and the labour.

Let us assume all the hypothesis of Solow's Growth Model.

The technological progress and the population growth rate are exogenous and constant: $\frac{d \ln A(t)}{d t}=g ; \frac{d \ln L(t)}{d t}=n$

Considering health as labour augmenting factor (Weil, 2005; Sala-i-Martin, 2005), the production function becomes

$$
Y(t)=K(t)^{a}(A(t) h(t) L(t))^{1-a}
$$




$$
\text { Being } \begin{aligned}
h=v y^{\theta}=v\left(\frac{Y}{L}\right)^{\theta} h=v Y^{\theta} L^{-\theta} \text { it obtains } \\
Y(t)=K(t)^{a}\left(A(t) v Y(t)^{\theta} L(t)^{(1-\theta)}\right)^{1-a} \text { or } \\
Y(t)=K(t) \frac{a}{1-\theta(1-a)}\left(A(t) v L(t)^{(1-\theta)}\right) \frac{1-a}{1-\theta(1-a)}
\end{aligned}
$$

It is also possible to write the eq. [23.] as

$$
Y(t)=K(t) \frac{a}{1-\theta(1-a)}\left(A(t) \frac{1}{1-\theta} v^{\frac{1}{1-\theta}} L(t)\right)^{\frac{(1-\theta)(1-a)}{1-\theta(1-a)}}
$$

The equation [24.] exhibits constant return to scale because $\frac{a+(1-\theta)(1-\alpha)}{1-\theta(1-\alpha)}=1$ If we put $a_{1}=\frac{a}{1-\theta(1-\alpha)}$ and $a_{2}=\frac{(1-\theta)(1-\alpha)}{1-\theta(1-\alpha)}=1-a_{1}$ then we have

$$
Y(t)=K(t)^{\alpha_{1}}\left(A(t) \frac{1}{1-\theta} v^{\frac{1}{1-\theta}} L(t)\right)^{1-a_{1}}
$$

This is again a Solow's Model with the "new" technological rate equal to $\frac{d \ln A_{2}(t)}{d t}=\frac{d \ln A(t)^{\frac{1}{1-\theta}}}{d t}=\frac{1}{1-\theta} g$

In steady state the Income growth rate and per capita income growth rate are

$$
\begin{aligned}
& \frac{d \ln Y(t)}{d t}=\left(\frac{1}{1-\theta}\right)(g+n) \\
& \frac{d \ln \frac{Y(t)}{L(t)}}{d t}=\left(\frac{1}{1-\theta}\right) g
\end{aligned}
$$

And the income level is

$$
\frac{Y(t)}{L(t)}=(A(0) v)^{\frac{1}{1-\theta}}\left[\frac{s}{\frac{g}{1-\theta}+n}\right]^{\frac{\alpha}{1-\theta[1-\alpha]}}
$$

Health growth and Health level are respectively 


$$
\begin{aligned}
& \frac{d \ln h(t)}{d t}=\left(\frac{\theta}{1-\theta}\right) g \\
& h(t)=v^{\frac{1}{1-\theta}}(A(0)) \frac{\theta}{1-\theta}\left[\frac{s}{\frac{g}{1-\theta}+n}\right]^{\frac{\alpha \theta}{1-\theta[1-\alpha]}}
\end{aligned}
$$

The first result we obtain is even if the Solow model with health remains an exogenous growth model, the parameter LRS positively affects income per capita growth and income per capita level in steady state. For example, if $\theta=0.5$ the income growth rate is equal to $2 \lambda$, while a negative LRS $(\theta<0)$ makes the income per capita to growth less than technological progress. In other words, a "good" lifestyle can improve the economic growth, while a "bad" lifestyle slows growth.

The second result is that Health growths less than income per capita and for $\theta<0$ health does not improve but worsen. This may be the case of a "Health Poverty trap".

Another issues is that in the micro model, the consumer can choose between two goods $x$ and $z$. But if the consumer can not purchase the $x$-good, the virtuous good, because it costs too much for his income (i.e. $p_{x} x>y$ ), the parameter $\theta$ will be negative. Let us consider x-good like a drug or a vaccine. To not afford the drugs for many people, can reduce the parameter $\theta$ and also the income growth rate.

In this context if the technological progress besides making the income growth, reduces the price of the virtuous goods, it may positively affect the parameter $\theta$ (it depends on whether the consumers will buy the new virtuous good).

\section{Conclusions}

In this paper I try to formalize what Jean Anthelme Brillat-Savarin, the author of Philosologie of taste, wrote two hundred years ago: (i) Animals feed themselves, men eat, but only wise men know the art of eating; and (ii) The destiny of nations depends on the manner in which they are fed.

The crucial hypothesis of the model are that (i) individuals can rationally choose to consume goods that affect health negatively; (ii) individuals are co-producers of their health and (iii) health affects labour productivity positively.

First, I develop a consumer's micro model with health and two goods. Both of them are positively correlated to the Consumer's Utility. Health is the output of a "consumer's production function" with the two goods as inputs. The first good has a positive impact on health while the second good has a negative impact.

The result is that the elasticity of consumer's income on health is on the parameter $\theta$, named lifestyle Return to scale, that is equal to the algebraic sum of the goods' elasticity with respect to health. It may be positive, negative or neutral. On the contrary to Wagstaff (1986) where health is a normal good in this model health can also be an 
inferior good.

Secondly, I computed the health multipliers. The main result is that the impact of a health shock on health and/or on income depends on labour share, and it is higher if the lifestyle Return to Scale is positive.

Thirdly, the micro-behaviour equation is introduced in Solow growth model in which the return to scale is constant. The result is that if lifestyle Return to scale is positive (and less than 1) the growth of income per capita is higher than the technical progress. In other words, Health affects labour efficiency. For these reasons many governments try to control. inhibit or incentivise consumer lifestyle. 


\section{Appendix}

\section{A generalizaton of Wagstaff's Model}

Starting from Michael Grossman's Model (1972), Wagstaff (1986) made a one period model of demand for health. The four hypothesis of the model are the following ones: 1) the individual's health is determined by the consumption of health inputs $h(x)=x^{\rho}$; 2 ) the preferences are non lexicographic: individuals desire health but not above all else; 3 ) the individuals also consume an other good that has a positive cost for the consumer So $U=u(h, z)$ with $\frac{d U}{d h}, \frac{d U}{d z}>0$ and $\left.\frac{d^{2} U(h, z)}{d h}, \frac{d^{2} U(h, z)}{d z}<0 ; 4\right)$ the consumer has limited economic resources or he has a budget constraint: $p_{x} x+p_{z} z=Y$ where $p_{x}$ and $p_{z}$ are respectively the prices of the goods $x$ and $z$ and and $Y$ the income.

Assuming a Cobb Douglas Utility function and a Health production function $h(x)=x^{\rho}$ the Wagstaff Model can also be formulated with the following formulas

$$
\begin{aligned}
& U(h, z)=h^{\alpha} z^{\delta} \\
& h(x)=x^{\rho} \\
& p_{x} x+p_{z} z=Y
\end{aligned}
$$

Where $0<\alpha<1$ and $0<\delta<1$ are the elasticities of $\mathrm{x}$ and $\mathrm{z}$ and $0<\rho<1$ the elasticity of $\mathrm{x}$ with respect to $h$.

This is a special case of the Consumer's model $(\S 2)$ with $\beta=0$ (the good $x$ is not in the Consumer's utility function) and with $\gamma=0$ ( $z$ doesn't affect health).

The solutions can be obtained by two different methods. The first is proposed by Wagstaff

$$
\underset{h, z}{\operatorname{Max}} U(h, z)=h^{\alpha} z^{\delta} \text { s.t. } p_{x} h^{\frac{1}{\rho}}+p_{z} z=Y
$$

In this case the Budget Constraint is not linear. The consumer chooses between health and $z$. The second possible solution is

$$
\underset{x, z}{\operatorname{Max}} U(x, z)=x^{\rho \alpha} z^{\delta} \text { s.t. } p_{x} x+p_{z} z=Y
$$

The consumer chooses the quantities of $x$ and $z$ that maximize his utility Both methods give the same solutions:

$$
x=\frac{\alpha \rho}{\delta+\alpha \rho} \frac{Y}{p_{x}}
$$




$$
\begin{aligned}
& z=\frac{\delta}{\delta+\alpha \rho} \frac{Y}{p_{z}} \\
& h=\left(\frac{\alpha \rho}{\delta+\alpha \rho} \frac{Y}{p_{x}}\right)^{\rho}
\end{aligned}
$$

The main differences are: 1) in the Wagstaff model Health can only be a normal good because $\mathrm{dh} / \mathrm{dy}>0$. On the contrary in the model proposed in this paper Health may also be an inferior good; 2) this depends on the lifestyle of the consumer. 


\section{References}

Avitabile C. (2009), Does Conditionality Matter for Adults' Health? Evidence from a Randomized Experiment. CSEF Working Paper n. 222

Becker G.S., Grossman M. Kevin M. (1994), An Empirical Analysis of Cigarette Addiction, The American Economic Review, Vol 84, No 3, pp 396-418

Becker G.S., Murphy K.M. (1988), A Theory of Rational Addiction, The Journal of Political Economy, Vol. 96, No 4, pp. 675-700

Bennardo A. and Piccolo S. (2005), Competitive Markets and Endogenous Health Risks, CSEF Working Paper no 145

Berger M. C., Leigh J.P. (1989), Schooling, Self-Selection, and Health, The Journal of Human Resource, Vol. 24, No 3. (Summer, 1989), pp. 433-455

Blondel S., Lohéac Y., Rinaudo S. (2007), Rationality and drug use: An experimental approach, Journal of Health Economics, 26, 643-658

Borg, V., Kristensen, T.,(2000), Social class and self-rated health: can the gradient be explained by differences in life style or work environment? Social Science and Medicine 51, 1019-1030.

Brillat Savarin J.A. (2004), "The Phisiology of Taste", Kessinger Publishing

Contoyannis P. and Jones A.M. (2004), Socio-economic Status, Health and Lifestyle, Journal of Health Economics, 23, 965-995

Destefanis S. and Sena V. (2006), Health Capabilities and Functionings: An Empirical Analysis for the U.K: CSEF Working Paper n. 151

Fuchs, V., 1982. Time Preference and Health: An Exploratory Study. In: Fuchs, V. (Ed.), "Economic Aspects of Health". University of Chicago Press, pp. 93-120.

Fuchs, V., 1986. "The Health Economy", first ed. Harvard University Press, Cambridge, MA.

Grossman M. (1972), On the Concept of Health Capital and the Demand for Health, Journal of Political Economy, Vol. 80, No 2., pp. 223-255

Heshmati (2001) On the causality between GDP and Health Care Expenditure in Augmented Solow Growth Model SEE/EFI Working paper series in Economics and Finance n. 423

Hu, T.-W., Ren, Q.-F., Keeler, T., Bartlett, J. (1995), The demand for cigarettes in California and behavioural risk factors. Health Economics 4, 7-14.

Kenkel, D., (1991). Health behaviour, health knowledge and schooling. Journal of Political Economy 99, 287-305.

Kenkel, D., (1995). Should you eat breakfast? Estimates from health production functions. Health Economics 4,15-29. 
Kip Viscussi W. and Evans W. N. (1990), Utility Function that Depend on Health Status, American Economic Review, Vol. 80 No.3., pp. 353-374

Lòpez-Casasnovas and others (2005) "Health and economic growth: findings and policy implications" edited by Guillem López-Casasnovas, Berta Rivera, and Luis Currais. - Cambridge : MIT press,

Maddison A. (2003), The World Economy: historical Statistics. Paris: Development Centre of the Organisation for Economic Co-operation and Development

Mas-Colell A., Whinston M. Green J. (1995), Microeconomic Theory, Oxford University Press,

Riley J. C. (2005), "Estimates of Regional and Global Life Expectancy, 1800 -2001" Population and Development Review 31(3): 537-543

Rivera B. and Currais L. (1999a) 'Economic growth and health: direct impact or reverse causation?', Applied Economics Letters, 6:11, 761 -764

Rivera B. and Currais L. (1999b) "Income Variation and Health Expenditure: Evidence for OECD Countries" Review of Development Economics, 3(3) 258-267

Romer D. (1996) "Advanced Macroeconomics" McGraw-Hill

Sala-i-Martin X. (2005), On The Health-Poverty Trap, in Lòpez-Casasnovas and others (2005) "Health and economic growth: findings and policy implications" edited by Guillem López-Casasnovas, Berta Rivera, and Luis Currais. Cambridge : MIT press

Sassi F. and Hurst J. (2008) The Prevention of Lifestyle related Chronic Diseases: An Economic Frameword OECD Health Working Paper n.32

Solow, R. (1956) A Contribution to the Theory of Economic Growth. Quarterly Journal of Economics 70 (February) 65:94

Strauss J. (1986), "Does Better Nutrition Raise Farm Productivity?" Journal of Political Economy 94

Varian, H. (1992), "Microeconomic Analysis", Ill ed., Norton

Wagstaff A. (1986) The Demand for Health: A Simplified Grossman Model Bulletin of Economic Research 38:1, 1986, 0307-3378

Weil D. N. (2004) "Economic Growth", Addison-Wesley

Weil D. N. (2005), Accounting for the Effect of Health on Economic Growth, mimeo

Zargosky J. L. (2005) Health and wealth: The late-20th century obesity epidemic in the U.S. Economics and Human Biology Vol. 3 issue. 2 296-313 


\title{
CELPE's Discussion Papers
}

\author{
2010114 Teresa AMODIO \\ Methods of analysis of local tourist systems \\ $2009113 \quad$ Fernanda MAZZOTTA \\ The Effec tof Parental Background on Youth Duration of Unemployment \\ 2009112 Matteo FRAGETTA \\ Identification in Structural Vector Autoregressions Through Graphical Modelling \\ and Monetary Policy: A Cross-Country Analysis \\ 2009111 Bruna BRUNO, Damiano FIORILLO \\ Why without Pay? The Intrinsic Motivation between Investment and \\ Consumption in Unpaid Labour Supply \\ 2009110 Maria Rosaria GAROFALO, Annamaria NESE \\ Social Preferences and the Third Sector: Looking for a Microeconomic \\ Foundation of the Local Development Path \\ 2008109 Giorgia IOVINO \\ Gis, ricerca geografica e pianificazione urbanistica: un'applicazione \\ sul centro storico di Benevento \\ 2008108 Bruna BRUNO \\ La donna flessibile e il lavoro opportuno \\ 2008107 Damiano FIORILLO \\ Offerta di Attività Gratuita in Italia: una analisi micro-econometrica \\ 2007, 106 Shane Niall O'HIGGINS, Marcello D'AMATO, Floro Ernesto \\ CAROLEO, Adriana BARONE \\ Gone for Good? Determinants of School Dropout in Southern Italy \\ 2007, $105 \quad$ Ugo COLOMBINO, Annamaria NESE \\ Preference Heterogeneity in Relation to Museum Services \\ 2007, 104 Giuseppe CELI, Mario SPORTELLI \\ Harrod's Dynamics and the Kaldor-Thirlwall Export-led Growth \\ 2007, 103 Francesca BETTIO, Fernanda MAZZOTTA, Giovanni SOLINAS \\ Costs and prospects for home based Long Term Care in Northern Italy: the \\ Galca survey \\ 2007, 102 Lisa CROSATO, Sergio DESTEFANIS, Piero GANUGI \\ Technology and Firm Size Distribution: Evidence from Italian Manufacturing \\ 2007, 101 Guglielmo Maria CAPORALE, Alexandros KONTONIKAS \\ The Euro and Inflation Uncertainty in the european Monetary Union
}


2006, 100

2006, 99

2005, 98

2005, 97

2005, 96

2005, 95

2005, 94

2005,93

2005, 92

2005,91

2005, 90

2004,89

2004,88

2004,87
Francesco Paolo VOLPE

Principio democratico e giustizia nell'amministrazione

Niall O'HIGGINS

Still With Us After All of These Years: Trends in Youth Labour Market Entry, Home-Leaving And Human Capital Accumulation in Italy 1993-2003

Floro Ernesto CAROLEO, Gianluigi COPPOLA

The Impact of the Institutions on Regional Unemployment Disparities

Carlo ALTAVILLA, Antonio GAROFALO, Concetto Paolo VINCI

Is the Discouraged Worker Effect Time-Varying?

F. BUSATO, B. CHIARINI, P. DE ANGELIS, E. MARZANO

Capital Subsidies and Underground Production

Lucio Valerio SPAGNOLO, Mario CERRATO

No euro please, We're British!

Roberto BASILE, Mauro COSTANTINI, Sergio DESTEFANIS

Unit root and cointegration tests for cross-sectionally correlated panels.

Estimating regional production functions

Sergio DESTEFANIS, Raquel FONSECA

Matching Efficiency and Labour Market Reform in Italy. A Macroeconometric Assessment

Cesare IMBRIANI, Antonio LOPES

Banking System Efficiency and the Dualistic Development of the Italian

Economy in the Nineties

Carlo ALTAVILLA, Antonio GAROFALO, Concetto Paolo VINCI

Designing the Optimal Lenght of Working Time

Marco MANACORDA, Barbara PETRONGOLO

Regional Mismatch and Unemployment: Theory and Evidence from Italy, 19771998

\section{Roberta TROISI}

Teoria dell'impresa e responsabilità parapenale: le implicazioni organizzativogestionali

Roberta TROISI

Enti non profit: tipologie ed opzioni organizzative

Lavinia PARISI

La povertà: una rassegna sul confronto tra due approcci. Capability vs.

Unidimensionalità 
Giuseppe CELI

Quality Differentiation, Vertical Disintegration and the Labour Market Effetcs of Intra-Industry Trade

2004, $85 \quad$ Niall O'HIGGINS

Recent Trends in Youth Labour Martkets and Employment Policy in Europe and Central Asia

2004, 84 Carlo ALTAVILLA, Floro Ernesto CAROLEO

Evaluating Asimmetries in Active Labour Policies: The Case of Italy

2004, 83 Floro Ernesto CAROLEO, Francesco PASTORE

La disoccupazione giovanile in Italia. La riforma dei sistemi d'istruzione e di formazione professionale come alternativa alla flessibilità numerica per accrescere l'occupabilità

2004, 82 Francesco PASTORE, Izabela MARCINKOWSKA

The Gender Wage Gap among Young People in Italy

2004, $81 \quad$ Elisabetta MARZANO

Dual Labour Market Theories And Irregular Jobs: IsThere a Dualism Even in The Irregular Sector?

2004, $80 \quad$ Corrado ANDINI

Unemployment and Welfare Partecipation in a Structural VAR: Rethinking the 1990s in the United States

2004, 79 Floro Ernesto CAROLEO

Fondamenti teorici della rigidità salariale nell'ambito dei "Non Market clearing Models"

2004, 78 Adalgiso AMENDOLA, Floro Ernesto CAROLEO, Gianluigi COPPOLA Regional Disparities in Europe

2003, 77 Fernanda MAZZOTTA

Flessibilità, povertà e istruzione: un approccio Sen - istituzionale

2003, $76 \quad$ Adalgiso AMENDOLA, Annamaria NESE

Mobilità intergenerale nel livello d'istruzione nella società femminile italiana ed endogenità de titolo di studio in un modello di partecipazione alla Forza Lavoro.

2003, $74 \quad$ Antonio LOPES

Innovazione nel Sistema Creditizio del Mezzogiorno negli Anni Novanta

2003, 73 Sergio DESTEFANIS, Vania SENA

Public Capital and Total Factor Productivity New Evidence from the Italian

Regions

2003, 72 Giuseppina AUTIERO, Bruna BRUNO

Social Preferences in Wage Bargaining: a Neocorporatist Approach 
2003, 71 Gianluigi COPPOLA, Maria Rosaria GAROFALO, Fernanda MAZZOTTA Industrial Localisation and Economic Development. A Case Study

2002, 70 Francesco GIORDANO, Fernanda MAZZOTTA

Salario di Riserva, Probabilità di Occupazione ed Efficacia dell'Istruzione

Universitaria: un'Analisi sugli Studenti dell'Università di Salerno

2002, 69 Giuseppe RUSSO

Istituzioni del Mercato del Lavoro e Occupazione: dai Costi di Aggiustamento all'Appropriabilità

2002, 68 Floro Ernesto CAROLEO, Francesco PASTORE

Training Policy for Youth Unemployed in a Sample of European Countries

2002, 67 Maria Rosaria GAROFALO, Maria Rosaria SUPINO

II Disegno Normativo del Welfare Municipale in Italia come Strumento per lo Sviluppo Economico e l'Allargamento delle Opportunità Occupazionali. Una Lettura Neoistituzionale della L. 328/00

2002, $65 \quad$ Pietro SENESI

Cyclical dynamics under continuous time equilibrium

2001, 64 Marcello D'AMATO, Vincenzo GALASSO

E' la Riforma Dini Politicamente Sostenibile?

2001, 63 Sergio DESTEFANIS, Ornella Wanda MAIETTA

Assessing the Productive Efficiency of Non-Profit Organisations: a Comparative Analysis

2001, 62 Floro Ernesto CAROLEO, Francesco PASTORE

How fine targeted is ALMP to the youth long term unemployed in Italy?

2001, $61 \quad$ Paolo COCCORESE

Strategic Advertising for Entry Deterrence Purposes

2001,60 Alessandra AMENDOLA

Modelling Asymmetries in Unemployment Rate

2001, 59 Sergio DESTEFANIS

Differenziali Territoriali di Produttività ed Efficienza negli Anni '90: i Livelli e l'Andamento

2001,58 Giuseppina AUTIERO, Fernanda MAZZOTTA

Job Search Methods: the Choice between the Public and the Private Sector

2001, 57 Giuseppina AUTIERO, Bruna BRUNO, Fernanda MAZZOTTA

A Correspondence Analysis of Labour Market Institutions

2000, $56 \quad$ Giuseppina AUTIERO

Governmental Organized Learning and Coordination Problems: The case of Japan in 1950s 
2000, 55 Giuseppina AUTIERO, Fernanda MAZZOTTA

The Choice of Search Methods: Some Empirical Evidence from Italy

2000, $54 \quad$ Giuseppe CELI

The Impact of International Trade on Labour Markets. The Case of Outward Processing Traffic between the European Union and Central Eastern European Countries.

2000, 53 Giuseppe RUSSO, David VEREDAS

Institutional Rigidities and Employment on the Italian Labour Market: the Dynamic of the Employment in the Large Industrial Firms.

2000, 52 Floro Ernesto CAROLEO

Le Politiche per l'Occupazione in Europa: una Tassonomia Istituzionale

2000, $51 \quad$ Andrew NEWELL, Francesco PASTORE

Regional Unemployment and Industrial Restructuring in Poland

1999, $50 \quad$ Giuseppe CELI, Alasdair SMITH

Quality Differentiation and the Labour Market Effects of International Trade.

1999, 49 Giuseppe CELI

Vertical and Horizontal Intra-Industry Trade: What is the Empirical Evidence for the UK?

1999, 48 Cesare IMBRIANI, Filippo REGANATI

Productivity spillovers and regional differences: some evidence on the italian manufacturing sector.

1999, 47 Adalgiso AMENDOLA, Annamaria NESE

L'impatto del background familiare sul livello d'istruzione dei figli.

1998, 46 Adalgiso AMENDOLA, Annamaria NESE

Mobilità intergenerazionale nella società femminile italiana.

1998, $45 \quad$ Floro Ernesto CAROLEO, Fernanda MAZZOTTA

Youth Unemployment and youth employment policies in Italy.

1997, $44 \quad$ Annamaria NESE

Mobilità intergenerazionale in Italia

1997, 43 Adriana BARONE, Concetto Paolo VINCI

Fairness: un concetto relativo nell'analisi del mercato del lavoro

1997, 42 Adriana BARONE, Concetto Paolo VINCI

Wage differentials and factor intensity reversals

1997, $41 \quad$ Rosa CAPOLUPO

L'ipotesi di convergenza nel recente dibattito sulle teorie della crescita

1997, $40 \quad$ Rosa CAPOLUPO

Endogenous Vs exogenous models of growth: the convergenze debate 
1997, 39 Fernanda MAZZOTTA, Annamaria NESE

Transizioni "In and Out" il mercato del lavoro in Italia: un'analisi

microeconometrica

1997, $38 \quad$ Fernanda MAZZOTTA

Disoccupazione e probabilità di occupazione in Italia: un'analisi su microdati

1997, 37 Maria Rosaria GAROFALO, Bruna BRUNO

Equivalenza istituzionale" dei modelli di contrattazione sul salario: oltre il dibattito tra centralizzazione e decentramento

1997, 36 Adalgiso AMENDOLA, Floro Ernesto CAROLEO, Gianluigi COPPOLA

Differenziali territoriali nel mercato del lavoro e sviluppo in Italia

1996, $35 \quad$ Adalgiso AMENDOLA

Istituzioni e mercato del lavoro. Deregolazione, occupazione e paradigma istituzionale

1996, 33 Annamaria NESE

Modelli microeconometrici per l'analisi della domanda abitativa

1996, $32 \quad$ Annamaria NESE

Test semiparametrici per modelli parametrici

1996, $31 \quad$ Giuseppe CELI

Vertical intra-industry trade and skill intensity in Europe: a cross sector analysis

1996, $30 \quad$ Sergio DESTEFANIS

Nominal rigidities and real activity. A cross-industry analysis for Italy, 1951-93

1996, 29 Cesare IMBRIANI, Filippo REGANATI

International technology transfer into the italian manufacturing sector

1996, 28 Stefania di SERAFINO, Alberto GANDOLFI

The choice of the Government optimal procurement mechanism: the first-price sealed bid auction with one and/or two winners.

1996, 27 Raul de LUZENBERGER

Redistribution, and public debt with liquidity constraints

1996, 26 Bruno CHIARINI

Un modello VAR per la domanda di lavoro

1995, 25 Maria Rosaria CARILLO, Alberto ZAZZARO

Innovazione tecnologica e distruzione di capitale umano in un modello neoshumpeteriano di crescita.

1995, 24 Raul de LUZENBERGER

Macroeconomia e politiche redistributive: il caso di vincoli di liquidità

1995, 23 Annamaria NESE

Tenure choice and demand for housing in Italy 
1995, 21 Sergio DESTEFANIS, Michele LA ROCCA, Cosimo VITALE Forecasting train ticket sales with linear model-based approaches and with edats

1995, 20 Stefania di SERAFINO

Bounded rationality and incomplete contracts

1995, 19 Adalgiso AMENDOLA, Floro E. CAROLEO, Maria Rosaria GAROFALO Istituzioni, mercato del lavoro e decentramento delle decisioni.

1995, $18 \quad$ Niall O'HIGGINS

Why did the youth training scheme reduce the wages of young people? A story of human capital formation, reservation wages and job offers.

1994, 17 Antonio CARDONE

Misure di efficienza: alcuni aspetti teorici

1994, 16 Maria Rosaria GAROFALO, Luisa ZANCHI

Neo-corporativismo, centralizzazione e dispersione inter-settoriale dei salari.

1994, 15 Sergio DESTEFANIS

Allowing for frequency of negotiation in the aggregate wage equation. A study for Italian manufacturing, 1973/92.

1994, 14 Marcello D'AMATO

Tariffs for a foreign industry with market power under incomplete information on demand

1994, 13 Raul DE LUZENBERGER, Cesare IMBRIANI, Giancarlo MARINI

Sustainability Issues in the process of European Integration

1994, 12 Riccardo MARSELLI, Antonio CARDONE

Interdipendenza tra regioni: un'analisi su dati di Panel

1993, 11 Adriana BARONE, Concetto Paolo VINCI

Dilemma del prigioniero e persistenza della disoccupazione involontaria

1993, 10 Maria Rosaria CARILLO

Mutamenti strutturali ed offerta di lavoro.

1993, 9 Niall O'HIGGINS

The effectiveness of YTS in Britain: an analysis of sample selection in the determination of employment and earnings

1993, $8 \quad$ Giuseppe CELI

Politiche valutarie ed integrazione commerciale: l'esperienza dello SME negli anni '80 
1992, 7 Paolo COCCORESE

Attività innovativa e configurazione industriale

1992, 6 Maria Rosaria GAROFALO, Gian Luigi CORINTO

La Razionalità dell'Allocazione del Tempo di Lavoro in Agricoltura. Con

un'Applicazione Empirica ad un Sistema Locale attraverso la PL..

1992, 5 Adalgiso AMENDOLA, Maria SCATTAGLIA

Disoccupazione e Tassi di Attività nel Mezzogiorno

1992, 4 Floro Ernesto CAROLEO

La Disoccupazione Strutturale

1991, 3 Giovanni URGA

Dynamic Models of Labour Demand in the Italian Industrial Sector: Theories and Evidence from Panel Data

1991, 2 Adalgiso AMENDOLA

Teoria dei Contratti Impliciti. Rigidità del Salario e Disoccupazione

1991, $1 \quad$ Guido CELLA

Sulla Integrazione Produttiva Interregionale: il Caso del Mezzogiorno 
CELPE - Centro di Economia del Lavoro e di Politica Economica Università degli Studi di Salerno

ISSN $\quad 1970-4259$

ISBN 978-88-95406-05-3

Depositato ai sensi di Legge 